\title{
Bibliography
}

\section{Manuscripts and archives}

\section{Eton}

\section{Eton College Library}

Loo. I 14. La Divina Commedia di Dante Alighieri, ed. L. Pezzana (Venice:

Gaspari, 1827).

\section{London}

British Library

Gladstone's Papers

Add MS 44503, f. 6.

Add MS 44689, ff. 209-211.

Add MS 44726, f. 24.

Add MS 44731, f. 139 v.

Add MS 44792, ff. 63-65.

The National Archives (UCL Special Collection)

Barlow Papers

BARLOW/1-97/17-23 (Unpublished works).

BARLOW/1-97/24-29 (Unpublished works).

BARLOW/1-97/30-44 (Manuscript essays and lectures).

BARLOW/1-97/45/1-46/3 (Commentaries).

BARLOW/1-97/47/1-53 (Commentaries).

BARLOW/1-97/54-62 (Commentaries).

BARLOW/1-97/91-97 (Festivals of Dante). 


\section{Manchester}

\section{Manchester Libraries}

GB127.MISC/323/1-13 (Papers relating to the Manchester Dante Society, Manchester Libraries).

GB127.MISC/323/5 (William Warren Vernon's Letter to Sig. Valgimigli accepting the Honorary Membership of the Manchester Dante Society).

GB127.MISC/323/10 (Membership Card and Statutes of the Society, Papers relating to the Manchester Dante Society).

\section{The John Rylands Library}

MS. 1254, Letter from John Ruskin to Constance Hilliard, 31 October 1877.

JRL/6/1/3/6, E.A. Rylands, Letter to W. Linnell, 13 April 1896.

Archive of the University of Manchester

GB 133 DEM/1/2/1/3 (Papers relating to the Department of Extra-Mural Studies and Centre for Continuing Education).

\section{Oxford}

\section{Harris Manchester College Library}

MSS. Herford-Wicksteed 1-3 (Herford-Wicksteed Papers).

MSS. Wicksteed 1, 2 (Philip H. Wicksteed Papers).

Taylorian Library

GB 486 MSS. 18-20 (Papers relating to the Oxford Dante Society).

GB 486 MSS. 21-9 (Papers of Edward Moore relating to Dante).

\section{Weston Library}

GB 161 MSS. Toynbee (Paget Toynbee Manuscripts on Dante).

GB 161 MSS. Don. e.4-5 (Works of Paget Toynbee).

\section{Oxford University Archives}

Papers relating to the Oxford University Extension Lectures, tbd.

\section{Balliol College}

Letters from Maria Francesca Rossetti to Henry Longfellow. 


\section{Harvard}

\section{Houghton Library}

James Russell Lowell additional papers

bMS Am 1483.

Moore, Edward, 1835-1916. A.L.s. to [ ]; Oxford, 18 Jun 1889. 1s.(3p.).

\section{Printed sources}

\section{Works by Dante}

\section{Editions}

Alighieri, D. (1822) La Divina commedia col comento del Baldassare Lombardi, 5 vols (Padova: dalla tipografia della Minerva).

- (1826-27) La Divina Commedia di Dante Alighieri can comento analitico di Gabriele Rossetti: in sei volumi, 6 vols (London: John Murray).

- (1827) La Divina Commedia di Dante Alighieri, edizione formata sopra quella di Comino del 1727, per cura di Lorenzo Pezzana (Venezia: Gaspari).

- (1843-50) Delle Prose E Poesie Liriche Di Dante Allighieri, prima edizione illustrata con note di diversi, ed. by Alessandro Torri (Livorno: np, Livorno).

- (1862) La Divina Commedia di Dante Alighieri, edizione minore fatta sul testo dell'edizione critica di Carlo Witte (Berlin: R. L. von Decker).

- (1873-87) Opere minori di Dante Alighieri, annotato e illustrato da Pietro Fraticelli, 3 vols (Firenze: Barbera).

- (1874) Dantis Alligherii De monarchia libri III, codicum manuscriptorum ope emendatiper Carolum Witte (Vindobonae: Sumptibus Guillielmi Braumuller).

- (1876) La Vita nuova ... Ricorretta coll'ajuto di testi a penna ed illustrata da Carlo Witte (Liepzig: n. pub.).

- (1893) Vita Nuova di Dante Alighieri with Notes and Comments in English, ed. by Napoleone Perini (London: Hachette and Co.).

- (1894) Tutte le opere di Dante Alighieri nuovamente rivedute nel testo da E. Moore (Oxford: Nella Stamperia dell'Università).

- (1895) Tutte le opere di Dante Alighieri nuovamente rivedute nel testo da E. Moore con Indice dei nomi propri e delle cose notabili contenute nelle opere di Dante. Compilato da Paget Toynbee (Oxford: Nella Stamperia dell'Università). 
- (1895) Vita Nuova di Dante Alighieri Fiorentino (Oxford: Nella Stamperia dell'Università).

- (1897) Tutte le opere di Dante Alighieri nuovamente rivedute nel testo da E. Moore con Indice dei nomi propri e delle cose notabili contenute nelle opere di Dante. Compilato da Paget Toynbee, 2nd edn (Oxford: Nella Stamperia dell'Università).

- (1904) Tutte le opere di Dante Alighieri nuovamente rivedute nel testo da E. Moore, 3rd edn (Oxford: Nella Stamperia dell'Università).

- (1909) Tutte le opere di Dante Alighieri nuovamente rivedute nel testo dal dottore Edward Moore, ed. E. Moore (Chelsea: Folio Nella Stamperia Ashendeniana, Shelley House).

- (1924) Tutte le opere di Dante Alighieri, a cura di Edward Moore, nuovamente rivedute nel testo da Paget Toynbee, 4th edn (Oxford: Nella Stamperia dell'Università).

- (1995) Convivio, ed. by Franca Brambilla Ageno, 3 vols (Florence: Le Lettere).

- (2005) La Divina Commedia, ed. by Anna Maria Chiavacci Leonardi, 3 vols (Milano: Mondadori).

\section{Translations}

Alighieri, D. (1802) Dante Alighieri: The Divina Commedia, Translated into English Verse, with Preliminary, Essays, Notes, and Illustrations, ed. and trans. by Henry Boyd, 3 vols (London: Cadell and Davies).

- (1805) The Inferno of Dante Alighieri, trans. by the Rev. Henry Francis Cary 2 vols (London: Carpenter).

- (1814) The Vision, or, Hell, Purgatory, and Paradise of Dante Alighieri, trans. by the Rev. Henry Francis Cary, 3 vols (London: Taylor and Hessey).

- (1819) The Vision, or, Hell, Purgatory and Paradise of Dante Alighieri, trans. by the Rev. Henry Francis Cary, 3 vols (London: Taylor and Hessey).

- (1835) The Canzoniere of Dante [...] including the poems of the Vita Nuova and Convito, trans. by Charles Lyell (London: John Murray).

- (1842) The Poems of the Vita Nuova and Convito of Dante Alighieri, trans. by Charles Lyell (London: C. F. Molini).

- (1844) The Vision: or, Hell, Purgatory, and Paradise of Dante Alighieri, trans. by the Rev. Henry Francis Cary (London: William and Smith).

- (1850) The Vision, or, Hell, Purgatory and Paradise of Dante Alighieri, trans. by the Rev. Henry Francis Cary, new and corr. edn (London: Henry G. Bohn). 
- (1862) The Vita Nuova of Dante, translated, with an introduction and notes, by Theodore Martin (London: Parker, Son \& Burn).

- (1862-63) Dante's Divina Commedia: Translated into English, in the Metre and Triple Rhyme of the Original with Notes by Mrs Claudia H. Ramsay (London: Tinsley Bros).

- (1865) The Comedy of Dante Allighieri: The Hell, translated into blank verse by W. M. Rossetti, with intr. and notes (London: Macmillan).

- (1865) Dante Allighieri’s Göttliche Komödie. Uebersetzt von Karl Witte (Berlin: R. L. von Decker).

- (1865-67) The Divine Comedy of Dante Alighieri, trans. by Henry W. Longfellow (London: Routledge).

- (1867) The New Life of Dante Alighieri, trans. by Charles Eliot Norton (Boston: Ticknor and Fields).

- (1879) The 'De Monarchia' by Dante Alighieri, trans. by Frederick J. Church (London: Macmillan).

- (1887) Il Convito: The Banquet of Dante Alighieri: Translated by Elizabeth Price Sayer with an Introduction Henry Morley (London: G. Routledge and Sons).

- (1890) Dante's Treatise 'De Vulgari Eloquentia': Translated into English, with Explanatory Notes by A. G. Ferrers Howell (London: K. Paul, Trench, Trübner \& Co.).

- (1899) The Paradiso of Dante Alighieri, ed. by Herman Oelsner and trans. by Philip H. Wicksteed (London: J. M. Dent and Co.).

- (1892-99) The Purgatorio of Dante Alighieri: An Experiment in Literal Translation, trans. by Charles L. Shadwell, 2 vols (London: Macmillan and Co.).

- (1900-2) The Vision of Dante Alighieri. Translated by Henry Francis Cary. Revised, with an introduction, by Paget Toynbee, 3 vols (London: Methuen \& Co.).

- (1901) The Purgatorio of Dante Alighieri, ed. by Herman Oelsner and trans. by Thomas Okey (London: J. M. Dent \& Co.).

- (1902) Dante and Giovanni del Virgilio including a critical edition of the text of Dante's 'Eclogae latinae' and of the poetic remains of Giovanni del Virgilio, ed. and trans. by Philip H. Wicksteed and Edmund G. Gardner (Westminster: Constable \& Co.).

- (1903) The Convivio of Dante Alighieri, ed. and trans. by Philip H. Wicksteed (London: J. M. Dent).

- (1904) The Latin Works of Dante Alighieri, ed. and trans. by A. G. Ferrers Howell and Philip H. Wicksteed (London: J. M. Dent \& Co.).

- (1904) The Purgatorio and Paradiso of the Divina Commedia of Dante Alighieri, trans. by Catherine Potter (London: Digby, Long $\&$ Co.). 
- (1906) The Vita Nuova and Canzoniere of Dante Alighieri, trans. by Thomas Okey and Philip H. Wicksteed (London: J. M. Dent \& Co.).

- (1909) Quaestio de Aqua et Terra, trans. by Charles L. Shadwell (Oxford: Clarendon Press).

- (1915) The Paradise of Dante Alighieri: An Experiment in Literal Translation, trans. by Charles L. Shadwell, 2 vols (London: Macmillan and Co.).

- (1927) Dante's Eclogues: The Poetical Correspondence between Dante and Giovanni del Virgilio, trans. by Wilmon Brewer (Boston: Cornhill Publishing and Co.).

\section{Primary and secondary sources}

Aberdeen Daily Journal, 'Editorial', 18 February 1902, p. 7.

Academy, 'A Dante Lecturership at Oxford', May 1895, p. 426.

Acheson, K. (2019) 'Introduction: Marginalia, Reading and Writing', in Early Modern English Marginalia, ed. by Katherine Acheson (London: Routledge), pp. 1-12.

Allan, D. (2010) Commonplace Books in Georgian England (Cambridge: Cambridge University Press).

Altick, R. (1957) The English Common Reader: A Social History of the Mass Reading Public, 1800-1900 (Chicago: University of Chicago Press).

Anderson, R. D. (1995) Universities and Elites in Britain since 1800 (Cambridge: Cambridge University Press).

Anger, S. (2011) Victorian Interpretation (Ithaca: Cornell University Press). Armstrong, E. (1969) 'Edward Moore, 1835-1916', in Edward Moore, Studies in Dante. First Series (Oxford: Clarendon Press), pp. ix-xxii.

Armstrong, G. (2013) The English Boccaccio: A History in Books (Toronto: University of Toronto Press).

Arnold, M., 'Dante and Beatrice', Fraser's Magazine, May 1863, pp. 665-9. - (1869) Culture and Anarchy: An Essay in Political and Social Criticism (London: Smith, Elder and Co.).

- (1880) 'The Study of Poetry', in The English Poets, 5 vols, ed. by Thomas H. Ward (London: Macmillan and Co.), I, pp. xvi-xlvii.

- (1882) 'Ecce, Convertimur ad Gentes', in Irish Essays and Others (London: Smith, Elder and Co.), pp. 109-39.

- (1902) Matthew Arnold's Notebooks, ed. by Eleanor M. C. A. W. M. Sandhurst (London: Smith Elder and Co.).

- (1952) The Notebooks of Matthew Arnold, ed. by Howard Foster Lowry, Karl Young, and Waldo Hilary Dutton (London: Oxford University Press). 
- (1958) Matthew Arnold's Books: Towards a Publishing Diary, ed. by William E. Buckler (Genève: Librairie E. Droz).

- (1959) Matthew Arnold's Diaries, the Unpublished Items: A Transcription and Commentary, ed. by William B. Guthrie (Charlottesville: University of Virginia).

- (1960) Essays, Letters, and Reviews by Matthew Arnold, ed. by Fraiser Neiman (Cambridge: Harvard University Press).

- (1960-77) 'Preface to First Edition of Poems (1853)', in The Complete Prose Works of Matthew Arnold, ed. by Richard Super, 11 vols (Ann Arbor: University of Michigan Press), I, 1-15.

- (1978) Unpublished Letters of Matthew Arnold, ed. by Arnold Whitridge (Folcroft: Folcroft Library Editions).

- (1979) Matthew Arnold, Prose Writings: The Critical Heritage, ed. by Carl Dawson and John Pfordresher (London: Routledge \& K. Paul).

- (1996-2001) The Letters of Matthew Arnold, ed. by Cecil Y. Lang, 6 vols (Charlottesville: University Press of Virginia).

Athenaeum, 'The Bargello of Florence', 25 December 1847, pp. 1328-9.

— 'The Vita Nuova of Dante', 8 February 1862, pp. 188-9.

- 'Dante's Divina Commedia', 5 March 1864, pp. 332-3.

- 'List of Some of the Principal New Books in Circulation at Mudie's Select Library', 16 January 1872, p. 37.

— 'Dante Literature', 15 June 1889, pp. 753-5.

— 'The Oxford Dante', 15 December 1894, pp. 823-4.

Atherton, C. (2005) Defining Literary Criticism: Scholarship, Authority and the Possession of Literary Knowledge, 1880-2002 (Basingstoke: Palgrave Macmillan).

Atkinson, J. (2010) Victorian Biography Reconsidered: A Study of Nineteenth Century 'Hidden' Lives (Oxford: Oxford University Press).

Austin, A. (1906) 'Preface', in Dante Society, The Dante Society Lectures, 3 vols (London: 'Pall Mall' Press), II, pp. x-xviii.

Baker, W. (1977) The George Eliot and George Henry Lewes Library. An Annotated Catalogue of Their Books at Dr. Williams's Library, London. (New York and London: Garland).

Barlow, H. C. (1850) Remarks on the Reading of the 59th Verse of the 5th Canto of the Inferno (Privately printed).

- 'Dante's Portrait in the Bargello at Florence', Athenaeum, 1857, pp. 853-4.

- (1862a) Il Conte Ugolino e l'Arcivescovo Ruggieri: A Sketch from the Pisan Chronicles (London: Trübner and Co.).

- (1862b) Il Gran Rifiuto: What It Was, Who Made It, and How Fatal to Dante Allighieri, a Dissertation on Verses 58 to 63 of the $3 \mathrm{rd}$ Canto of the Inferno (London: Trübner and Co.).

- (1862c) Review of Theodore Martin's Translation of the Vita Nuova', Athenaeum, 8 February 1862. 
- (1864) Critical, Historical, and Philosophical Contributions to the Study of the Divina Commedia (London and Edinburgh: Williams \& Norgate).

- (1865a) Critical, Historical and Philosophical Contributions to the Study of the Divina Commedia (London: William and Norgate).

- (1865b) Francesca da Rimini: Her Lament and Vindication with a Brief Notice of the Malatesti (London: David Nutt).

- (1865c) The Sixth Centenary Festival of Dante Alighieri in Florence and at Ravenna (London: William and Norgate).

- (1866) The Sixth Centenary Festivals of Dante Alleghieri in Florence and Ravenna by A Representative (London, Edinburgh, Florence, and Turin: Williams \& Norgate and Hermann Loescher).

- (1868) A Brief Memoir of Henry Clark Barlow (London: Privately Printed).

- (1871) 'A Shadow of Dante: Being an Essay towards Studying Himself, His World, and His Pilgrimage. By Maria Francesca Rossetti (Rivingtons)', Athenaeum, 2297 (4 November), pp. 586-7.

Beatty, H. M. (1914) 'A Century of Cary's Dante', Studies: An Irish Quarterly Review, 3:9, pp. 567-82.

Bebbington, D. W. (1993) William Ewart Gladstone: Faith and Politics in Victorian Britain (Grand Rapids: W. B. Eerdmans Publisher).

- (2004) The Mind of Gladstone: Religion, Homer, and Politics (New York: Oxford University Press).

Bell, E. H., 'Dante's Vita Nuova', The Academy, 1869-1902, 11 December 1880, p. 425.

Bell, M. (1898) Christina Rossetti: A Biographical and Critical Study (Boston: Roberts Bros.).

Le Belle Assemblée, or, Bell's Court and Fashionable Magazine Addressed Particularly to the Ladies, 'European Literature of the Fourteenth Century', 1 July 1838, pp. 50-5.

Bennett, D. (1990) Emily Davies and the Liberation of Women: 1830-1921 (London: Andre Deutsch).

Berlin, J. A. (1983) 'Matthew Arnold's Rhetoric: The Method of an Elegant Jeremiah', Rhetoric Society Quarterly, 13, 29-40.

Blackwood's Edinburgh Magazine, 'On Public Lectures of Works Imagination at Literary Institutions', November 1819, pp. 162-9.

Boccaccio, G. (1833) La vita di Dante Alighieri (Firenze: per Ig. Moutier). Boldrini, L. (2001) Joyce, Dante, and the Poetics of Literary Relations: Language and Meaning in Finnegan's Wake (Cambridge: Cambridge University Press).

Boschi Rotiroti, M. (2015) 'English Intellectuals in the Archives of the Società Dantesca Italiana', Dante in the Nineteenth Century: The International Journal of Cross-Cultural Studies and Environmental Communication, 4.1, pp. 45-52. 
Botterill, S. (1993) 'Dante in the British Isles since 1980', Dante Studies, with the Annual Report of the Dante Society, 111, 245-61.

- (2005) 'The Trecento Commentaries on Dante's Commedia', in The Cambridge History of Literary Criticism, vol II, The Middle Ages, ed. by Alastair Minnis and Ian Johnson (Cambridge: Cambridge University Press), pp. 590-611.

Bradley, M. (2009) ““Annotation Mapping” and What It Means: Developing the Gladstone Catalogue as a Resource for the History of Reading', Literature Compass, 6, 499-510.

- (2015) 'Gladstone's Unfinished Synchrony: Reading Afterlives and the Gladstone Catalogue', in Reading and the Victorians, ed. by Matthew Bradley and Juliet John (Burlington: Ashgate), pp. 127-42.

Braida, A. (2004) Dante and The Romantics (Basingstoke and New York: Palgrave Macmillan).

- (2020) 'Mary Shelley in Italy: Reading Dante and the Creation of an Anglo-Italian Identity', L'analisi linguistica e letteraria, Vita e Pensiero, 17:3, pp. 107-18.

Brake, L. (1994) Subjugated Knowledges: Journalism, Gender and Literature in the Nineteenth Century (London: Macmillan).

Bryant, M. (1979) The Unexpected Revolution: A Study in the History of the Education of Women and Girls in the Nineteenth Century (London: University of London, Institute of Education).

Caesar, M. (1989) Dante: The Critical Heritage, 1314(?)-1870 (London: Routledge).

Caine, B. (1992) Victorian Feminists (Oxford: Oxford University Press).

Camilletti, F., M. Gragnolati, and F. Lampard, eds (2011) Metamorphosing Dante: Appropriations, Manipulations and Rewritings in the Twentieth and Twenty-First Centuries (Wien: Turia + Kant).

Camilletti, F. (2019) Portrait of Beatrice: Dante, D. G. Rossetti and the Imaginary Lady (Notre Dame: University of Notre Dame Press).

Carducci, G. (1888) L'opera di Dante (Bologna: Nicola Zanichelli).

Carlyle, T. (1841) On Heroes, Hero Worship and The Heroic in History: Six Lectures (London: James Fraser).

- (1892) Lectures on The History of Literature: Or the Successive Periods of European Culture delivered in 1838 (London: Curwen, Kane).

Cary, H. (1847) Memoir of the Rev. Henry Francis Cary, M.A., Translator of Dante: With His Literary Journal and Letters, 2 vols (London: E. Moxon).

Caselli, D. (2017) 'Dante's Pilgrimage in Dorothy Richardson', Comparative Literature, 69, pp. 91-110.

Chadwick, O. (1979) 'Young Gladstone and Italy', Journal of Ecclesiastical History, 10, pp. 243-59. 
Chapman, A. (2000) The Afterlife of Christina Rossetti (Basingstoke: Palgrave Macmillan).

Chapman, A. and J. Meacock, eds (2007) A Rossetti Family Chronology (Basingstoke: Palgrave Macmillan).

Chester, N. (1895) Dante Vignettes (London: Elliot Stock).

Chiavacci, A. M., ed. (2005) La Divina Commedia, 3 vols (Milano: Mondadori).

Church, R. C. (1888) Dante and Other Essays (London: Macmillan and Co.).

Clark, P. (2000) British Clubs and Societies 1580-1800: The Origins of an Associational World (Oxford: Oxford University Press).

Coleridge, S. T. (1836-59) The Literary Remains of Samuel Taylor Coleridge, ed. by Henry Nelson Coleridge, 4 vols (London: Pickering).

- (1957-89). The Notebooks of Samuel Taylor Coleridge, ed. by Kathleen Coburn, 6 vols (New York: Princeton).

- (1987a) The Collected Works of Samuel Taylor Coleridge, ed. by R. A. Foakes, 16 vols (Princeton: Princeton University Press), V, pp. 401-2.

- (1987b) Lectures 1808-1819 on Literature, ed. by R. A. Foakes, 2 vols (London and Princeton: Routledge and Princeton University Press).

- (2003) A Book I Value: Selected Marginalia, ed. by H. J. Jackson (Princeton: Princeton University Press).

Collini, S. (1994) Matthew Arnold: A Critical Portrait (Oxford: Clarendon Press).

Colombo, D. (2011) 'Per l'edizione del Commento Dantesco dI Baldassarre Lombardi', Rivista di Studi Danteschi, XI, pp. 322-73.

Coluzzi, F. (2021) 'Rossetti Reconsidered: Dante's Vita Nuova and Its Paths to Canonization in Victorian Literary Culture', Le Tre Corone: Rivista Internazionale di studi su Dante, 8, pp. 135-46.

Connell, P. (2000) 'Bibliomania: Book Collecting, Cultural Politics, and the Rise of Literary Heritage in Romantic Britain', Representations, 71, pp. 24-47.

Connell, W. F. (1950) The Educational Thought and Influence of Matthew Arnold (London: Routledge \& K. Paul).

Cooksey, T. L. (1984) 'Dante's England: The Contribution of Cary, Coleridge and Foscolo to the British Reception of Dante', Papers on Language and Literature, 20, pp. 355-81.

Coolahan, M. L. (2020) 'The Cultural Dynamics of Reception', Journal of Medieval and Early Modern Studies, 50:1, pp. 1-12.

Cortese, R. (1981) George Eliot and Dante, unpublished PhD, University of Winsconsin-Madison.

Cotes, R. A. (1898) Dante's Garden, with the Legend of the Flowers (London: Methuen \& Co.). 
Crisafulli, E. (2003) The Vision of Dante: Cary's Translation of the Divine Comedy (Market Harborough: Troubador).

The Critic, 'Mr Martin's Dante', 1862, pp. 338-40.

Cunningham, G. F. (1965-66) The Divine Comedy in English: A Critical Bibliography 1782-1900, 2 vols (Edinburgh and London: Oliver and Boyd).

D'Israeli, I. (1795) An Essay on the Manners and Genius of the Literary Characters (London: printed for T. Cadell, Jr and W. Davies).

Dacome, L. (2005) 'Noting the Mind: Commonplace Books and the Pursuit of the Self in Eighteenth-Century Britain', Journal of the History of Ideas, 65, pp. 603-25.

Daily News, 'The Age of Dante', 22 April 1857, p. 2.

- 'Signor Nicolini's Lectures on Dante', 30 January 1860, p. 2.

Dante Society (1904-6) The Dante Society Lectures, 3 vols (London: Pall Mall Press).

Darnton, R. (1990) The Kiss of Lamourette: Reflections in Cultural History (London, Faber).

- (2000) 'Extraordinary Commonplaces', New York Review of Books, 20, pp. 82-7.

Daunton, M., ed. (2005) The Organisation of Knowledge in Victorian Britain (Oxford: Published for the British Academy by Oxford University Press).

Davie, M. (1994) “Not an After-Dinner Relaxation”: Gladstone on Translating Dante', Journal of European Studies, 2, pp. 385-40.

Davies, E. (1866) The Higher Education of Women (London: Alexander Straham).

- (1910) Thoughts on Some Questions Relating to Women, 1860-1908 (Cambridge: Bowes and Bowes).

- (2004) Emily Davies: Collected Letters, 1861-1875, ed. by A. Murphy and D. Raftery (Charlottesville: University of Virginia Press).

Denman, K. and S. Smith (1994) 'Christina Rossetti’s Copy of C. B. Cayley's Divine Comedy', Victorian Poetry, 32:2-4, pp. 315-38.

Dennett, J. R., 'A Review of Miss M. F. Rossetti's Shadow of Dante', The Nation, 1872, pp. 28-9.

De Ventura, P. (2011) 'Introduzione', in Maria Francesca Rossetti, Un'ombra di Dante: ovvero un saggio per studiare l'autore, il suo mondo e il suo pellegrinaggio, ed. and trans. by Paolo De Ventura (Lanciano: Rocco Carabba), pp. 9-71.

Donovan, R. A. (1956) 'The Method of Arnold's Essays in Criticism', PMLA, 71, pp. 922-31.

Doughty, O. (1953) 'Dante Gabriel Rossetti as Translator', Theoria: A Journal of Social and Political Theory, 5, 102-12. 
Draper, W. H. (1923) University Extension: A Survey of Fifty Years 18731923 (Cambridge: Cambridge University Press).

Drury, A. (2015) Translation as Transformation in Victorian Poetry (Cambridge: Cambridge University Press).

Dublin Review, 'Tutte le Opere di Dante Alighieri: Nuovamente Rivedute Nel Testo’, April 1895, pp. 425-7.

Edinburgh Evening News, 'Mr Gladstone on Dante', 22 January 1884, p. 4. - 'Mr Gladstone on Dante', 14 March 1896, p. 4.

Eliot, S. (2006) 'Circulating Libraries in the Victorian Age and After', in The Cambridge History of Libraries in Britain and Ireland, ed. by Alistair Black and Peter Hoare, 3 vols (Cambridge: Cambridge University Press), III, pp. 125-146.

- (2007) 'From Few and Expensive to Many and Cheap: The British Book Market 1800-1900', in The Blackwell Companion to the History of the Book, ed. by Simon Eliot and Jonathan Rose (Oxford: Blackwell), pp. 291-302.

Eliot, T. S. (1932) 'Matthew Arnold' in Selected Essays, 1917-1932 (New York: Harcourt, Brace), pp. 346-56.

Ellis, H. (2014) 'Enlightened Networks: Anglo-German Collaboration in Classical Scholarship' in Anglo-German Scholarly Networks in the Long Nineteenth Century, ed. by Heather Ellis and Ulrike Kirchberger (Leiden: Brill), pp. 21-38.

Ellis, S. (1983) Dante and English Poetry: Shelley to T. S. Eliot (Cambridge: Cambridge University Press).

Ellison, R. H. (1998) The Victorian Pulpit: Spoken and Written Sermons in Nineteenth-Century Britain (Cranbury: Susquehanna University Press).

Ferris, I. (2004) 'Bibliographical Romance: Bibliophilia and the BookObject', in Romantic Libraries, ed. by Ina Ferris, Romantic Circles (25 October 2004).

Flint, K. (1993) The Woman Reader: 1837-1914 (Oxford: Oxford University Press).

Folena, G. (1965) 'La filologia dantesca di Carlo Witte', in Dante e la cultura tedesca. Convegno di studi danteschi, 1965, ed. by Lino Lazzarini (Padua: Tipi dell'Antoniana, 1967), pp. 111-39.

- (1967) 'La filologia dantesca di Carlo Witte', in Dante e la cultura tedesca. Convegno di studi danteschi, 1965, ed. by Lino Lazzarini (Padua: Tipi dell'Antoniana), pp. 111-39.

Foot, M. R. D. (1968-94), 'Introduction', in The Gladstone Diaries, ed. by M. R. D. Foot and H. C. G. Matthew, 14 vols (Oxford: Oxford University Press), pp. xix-xlviii.

Foscolo, U. (1917) Poesie, lettere e prose letterarie / di Ugo Foscolo; scelte ed annotate per le scuole classiche da Tommaso Casini (Florence: Sansoni). 
- (1972) Studi su Dante, ed. by Giovanni da Pozzo, Edizione nazionale delle opere di Ugo Foscolo, 22 vols, IX.

Foster, K. (1965) 'Dante Studies in England, 1921-1964', Italian Studies, 20, pp. 1-16.

Fowler, A. (1979) 'Genre and the Literary Canon', New Literary History, 11, pp. 97-119.

Fraser's Magazine for Town and Country, 'The Vita Nuova of Dante', May 1862, pp. 580-94.

Fredeman, W. E. (1996) “"Woodman, Spare that Block”: The Published, Unpublished, and Projected Illustrations and Book Designs of Dante Gabriel Rossetti', Journal of Pre-Raphaelite Studies, 5.1 (1996), pp. 7-41.

Friedrichs, H. (1896) In the Evening of His Days: A Study of Mr. Gladstone in Retirement, with Some Account of St. Deiniol's Library and Hostel (London: Westminster Gazette).

Gardner, E. G. (1899) The Paradiso of Dante Alighieri, ed. by Herman Oelsner and trans. by Philip H. Wicksteed (London: J. M. Dent and Co.). - (1900) Dante (London: J. M. Dent).

Genette, G. (1997) Paratexts: Thresholds of Interpretation, trans. by Jane E. Lewin (Cambridge: Cambridge University Press).

Gentleman's Magazine, 'Historical Influences of the Divine Comedy', February 1900, pp. 167-76.

Gentleman's Magazine: And Historical Review, 'Portrait of Dante', January 1841, p. 73.

Gilson, S. (1995) Dante and Renaissance Florence (Cambridge: Cambridge University Press).

- (2018) Reading Dante in Renaissance Italy (Cambridge: Cambridge University Press).

Gifford, G. H. (1956) 'A History of the Dante Society', Annual Reports of the Dante Society, with Accompanying Papers, 74 (1956), 3-27.

Gittings, R. (1956) The Mask of Keats: A Study of Problems (Cambridge: Harvard University Press).

Gladstone, M. (1930) Mary Gladstone, Her Diaries and Letters, 18701886, ed. by Lucy Masterman (London: Methuen \& Co.).

Gladstone, W. E. (1884) 'Lord John Russell's Translation of Dante's Francesca da Rimini', English Review, April 1884, pp. 1-16.

- (1892) 'Did Dante Study at Oxford?', Nineteenth Century Review, June, pp. 1032-42.

- (1930) The Gladstone Papers, ed. by A. Tilney Bassett (London: Cassell).

- (1968-94) The Gladstone Diaries, ed. by M. R. D. Foot and H. C. G. Matthew, 14 vols (Oxford: Oxford University Press).

Glasgow Herald, 'Our London Correspondence', 21 November 1894, p. 5. Gottfried, L. A. (1963) Matthew Arnold and the Romantics (Lincoln: University of Nebraska Press). 
Gow, E. (2019a) 'Feature Article: Enriqueta Rylands: A Study of Private Collecting and Public Philanthropy, 1889-1908', Library and Informational History Group News, Winter, pp. 2-4.

- (2019b) 'Enriqueta Rylands: The Private Collector of a Public Library', unpublished paper.

- (2020) “"Not Slothful in Business": Enriqueta Rylands and the John Rylands Library', in Protestant Dissent and Philanthropy in Britain, 1660-1914, ed. by Clyde Binfield, G. M. Ditchfield, and David L. Wykes (Cambridge: Boydell and Brewer), pp. 205-22.

Grafton, A. (1997) 'Is the History of Reading a Marginal Enterprise? Guillaume Budé and His Books', The Papers of the Bibliographical Society of America, 91, pp. 139-57.

Griest, G. L. (1965) 'A Victorian Leviathan: Mudie’s Select Library', Nineteenth-Century Fiction, 20, pp. 103-26.

Guppy, H. (1908) 'In Memoriam. Mrs Enriqueta Augustina Rylands', Bulletin of the John Rylands Library, 1:6, p. 355.

Guppy, H. and John Rylands Library (1909) Catalogue of an Exhibition of the Works of Dante Alighieri: Shown in the John Rylands Library, Manchester from March to October 1909 (Manchester: Sherratt and Hughes).

Hampton, T. (1990) Writing from History: The Rhetoric of Exemplarity in Renaissance Literature (Ithaca: Cornell University).

Harding, A. J. (2004) 'Coleridge's Notebooks and the Case for a Material Hermeneutics of Literature', Romanticism, 1, pp. 1-19.

Harrison, A. H. (2009) The Cultural Production of Matthew Arnold (Athens: Ohio University Press).

Hartley, R. A. (1990) 'Shelley's Copy of Dante', Keats-Shelley Journal, 39, pp. 22-9.

Hasell, E. J. (1867) 'Dante in English Terza Rima', Blackwood's Edinburgh Magazine, June 1867, pp. 736-55.

Havely, N. R., ed. (2011) Dante in the Nineteenth Century: Reception, Canonicity, Popularisation (Oxford: Peter Lang).

- (2014) Dante's British Public: Readers and Texts, from the Fourteenth Century to the Present (Oxford: Oxford University Press).

- (2018) 'Wider Circles: Popularizing Dante, from Temple Classics to Penguin Classics In Journey through Changing Landscapes' in Literature, Language, Culture and Their Transnational Dislocations, ed. by Carla Dente and Francesca Fedi (Pisa: Pisa University Press).

Havens, E. (2001) Commonplace Books: A History of Manuscripts and Printed Books from Antiquity to the Twentieth Century (New Haven: Yale University Press). 
Hazlitt, W. (1930-34) 'Lectures on the English Poets', in The Complete Works of William Hazlitt, ed. by P. P. Howe, 21 vols (London: J. M. Dent), V, pp. 15-19.

Herford, C. H. (1931) Philip Henry Wicksteed, His Life and Work (London: J. M. Dent).

Hess, J. (2012) 'Coleridge's Fly-Catchers: Adapting Commonplace-Book Form', Journal of the History of Ideas, 73:3, pp. 463-83.

Hessel, K. (2016) 'The Romantic-Era Lecture: Dividing and Reuniting the Arts and Sciences', Configurations, 24, pp. 501-32.

Heyck, T. W. (1982) The Transformation of Intellectual Life in Victorian England (London: Croom Helm).

Hodgson, J. (2012) “"Carven stone and blazoned pane": The Design and Construction of the John Rylands Library', Bulletin of the John Rylands Library, 89:1, pp. 19-81.

Holbrook, R. (1911) Portraits of Dante from Giotto to Raffael: A Critical Study, with a Concise Iconography (London: P. L. Warner).

Hollander, R. (1983) 'A Checklist of Commentators on the Commedia (1322-1982)', Dante Studies, with the Annual Report of the Dante Society, 101, pp. 181-92.

- (2007) 'Dante and his Commentators', in The Cambridge Companion to Dante, ed. by Rachel Jacoff (Cambridge: Cambridge University Press), pp. 270-80.

Houghton, W. E. (1982) 'Periodical Literature and the Articulate Classes', in The Victorian Periodical Press: Samplings and Soundings, ed. by Joanne Shattock and Michael Woolf (Leicester: Leicester University Press), pp. 3-28.

Isba, A. (2006) Gladstone and Dante: Victorian Statesman, Medieval Poet (Royal Historical Society, London: Boydell Press).

Jackson, H. J. (2001) Marginalia: Readers Writing in Books (New Haven: Yale University Press).

- (2005) Romantic Readers: The Evidence of Marginalia (New Haven and London: Yale University Press).

- (2012) 'Coleridge As Reader: Marginalia', in The Oxford Handbook of Samuel Taylor Coleridge, ed. by Frederick Burwick (Oxford: Oxford University Press), pp. 271-87.

Jagger, P. J. (2007) Gladstone (London: Continuum).

Jennings, J. (1823) A Lecture on the History and Utility of Literary Institutions (London: Sherwood, Jones).

Jepson, N. A. (1973) The Beginnings of English University Adult Education: Policy and Problems: A Critical Study of the Early Cambridge and Oxford University Extension Lecture Movements between 1873 and 1907, with Special Reference to Yorkshire (London: Joseph). 
Joeres, R. B. and E. Mittman, eds (1993) The Politics of the Essay: Feminist Perspectives (Bloomington: Indiana University Press).

Johnston, J. and H. Fraser (2001) 'The Professionalization of Women's Writing: Extending the Canon', in Women and Literature in Britain, 1800-1900, ed. by J. Shattock (Cambridge: Cambridge University Press). Kargon, R. H. (1977) Science in Victorian Manchester: Enterprise and Expertise (Regno Unito: Manchester University Press).

Keats, J. (1958) The Letters of John Keats, ed. by Hyder Edward Rollins, 2 vols (Cambridge: Cambridge University Press).

King, R. W. (1925) The Translator of Dante (London: Secker).

Kirchberger, U. (2014) 'Introduction', in Anglo-German Scholarly Networks in the Long Nineteenth Century, ed. by Heather Ellis and Ulrike Kirchberger (Leiden: Brill), pp. 1-19.

Kirsch, A. (2008) The Modern Element: Essays on Contemporary Poetry (New York: W. W. Norton).

Klancher,J. (2013) Transfiguring the Arts and Sciences: Knowledge and Cultural Institutions in the Romantic Age (Cambridge: Cambridge University Press). Kuhns, O. (1904) Dante and the English Poets (London: Bell). Landor, W., 'Fine Arts', Examiner, 16 August 1840, p. 518.

Lau, B. (1994) 'Editing Keats's Marginalia', Text, 7, pp. 337-48.

- (1996) 'Keats and the Practice of Romantic Marginalia', Romanticism, 2:1, pp. 40-53.

- (1998) Keats's Paradise Lost (Gainesville: University Press of Florida).

- (2006) 'Analyzing Keats's Library by Genre', Keats-Shelley Journal, 65, pp. $126-51$.

Laurence, A., J. Bellamy, and G. Perry (2000) Women, Scholarship and Criticism C. 1790-1900, ed. by Anne Laurence, Joan Bellamy, Gill Perry (Manchester: Manchester University Press).

Laurence, A. (2011) 'Exploiting Dante: Dante and His Women Popularizers, 1850-1910', in Dante in the Nineteenth Century: Canonicity, Reception, Popularisation, ed. by Nicholas Havely (Oxford: Peter Lang), pp. 281-301.

Lawrie, A. (2014) The Beginnings of University English: Extramural Study, 1885-1910 (Basingstoke: Palgrave Macmillan).

Levine, P. (2002) 'Keats against Dante: The Sonnet on Paolo and Francesca', Keats-Shelley Journal, 51, pp. 76-93.

Lindon, J. (1977) 'One Hundred Years of Barlow Lectures', Italian Studies, 32 (1977), pp. 8-20.

- (1988) 'H. C. Barlow and His Contribution to Textual Criticism of the Divine Comedy', Deutsches Dante-Jahrbuch, 63, pp. 47-74.

- (1989) 'Henry Clark Barlow and Karl Witte: A Friendship in Dante, with Unpublished Letters', Deutsches Dante-Jahrbuch, 64, pp. 75-110. 
- (1995) 'Gli apporti del metodo di Edward Moore nei primi decenni della Società Dantesca Italiana', in La Società Dantesca Italiana, 1888-1988: Convegno Internazionale, Firenze 24-26 Novembre 1988 (Milan and Naples: Ricciardi), pp. 37-53.

- (2000) 'Dante "intra Tamisi ed Arno" (and Halle-am-Saale): The Letters of Seymour Kirkup to H. C. Barlow', in Britain and Italy from Romanticism to Modernism: A Festschrift for Peter Brand, ed. by Martin McLaughlin (London: Routledge), pp. 121-42.

- (2010) 'Notes on the British Contribution to the Nineteenth-Century Rise of Dante Studies: Edward Moore and the Text of the Commedia', in Dante the Lyric and Ethical Poet: Dante lirico e etico, ed. by Zygmunt G. Barański and Martin L. McLaughlin (London: Legenda, MHRA and Maney Publishing), pp. 227-35.

- (2013) 'Notes on Nineteenth-Century Dante Commentaries and Critical Editions', in Interpreting Dante: Essays on the Traditions of Dante Commentary, ed. by P. Nasti and C. Rossignoli (Notre Dame: University of Notre Dame Press), pp. 434-49.

Liverpool Mercury, 'Our London Letter', 1 November 1894, p. 7.

Lloyd, J. M. (1995) 'Raising Lilies: Ruskin and Women', Journal of British Studies, 34, pp. 325-50.

London Dante Society and L. Ricci (1908) Annual Report Read at the Meeting of June 4th, 1908 ([London?]: [n. pub.]).

London Quarterly Review, 'The Vita Nuova, or New Life of Dante Alighieri', April 1903, p. 407.

London Review, 'Translations of Dante', 30 May 1863, pp. 585-6.

London Standard, 'Mr. Gladstone and Dante', 9 January 1884, p. 5.

Lowell, J. R., 'The Shadow of Dante, Being an Essay towards Studying Himself, His World, and His Pilgrimage by Maria Francesca Rossetti', North American Review, July 1872, p. 139.

- (1898-99) 'Dante', in The Writings of James Russell Lowell, 11 vols (Boston: Houghton, Miffin and Co.), IV, pp. 118-264.

Lubenow, W. (2015) 'Only Connect': Learned Societies in NineteenthCentury Britain (Woodbridge: Boydell Press).

Lyell, C. (1845) 'Preface', in The Lyrical Poems of Dante including the poems of the Vita Nuova and Convito (London: W. Smith), pp. v-vii.

Lyttelton, G. (1861) Translations by Lord Lyttelton and the Rt. Hon. W. E. Gladstone (London: Quaritch).

Macaulay, T. B. 'Criticism on the Principal Italian Writers. Dante', Knight's Quarterly, 2, 1824, pp. 207-23.

- 'Dante and Milton', Edinburgh Review, 1825, pp. 306-23.

Manchester Courier and Lancashire General Advertiser, 'Local Intelligence', 7 October 1846, p. 4. 
- 'Mr. Gladstone and Dante', 22 January 1884, p. 8.

- 'Gossip of the Week', 3 November 1894, p. 2.

- 'Mr. Gladstone and Dante', 15 October 1895, p. 8.

- 'Dante Society', September 1906, p. 10.

— 'Dante Society', 18 December 1908, p. 7.

Manchester Guardian, 'Dante's Treatment of Women: A Discussion by the Society’, 28 January 1908, p. 9.

Manchester Times, 'Manchester Royal Institution', 18 March 1854, p. 12.

Marsh, J. (1994) Christina Rossetti: A Literary Biography (J. Cape: University of Michigan).

Marriott, S. (1981) A Backstairs to a Degree: Demands for an Open University in Late Victorian England (Leeds: Department of Adult Education and Extramural Studies, University of Leeds).

Matthew, C. (1999) 'Gladstone and His Diaries', Flintshire Historical Society Journal, 35, pp. 167-75.

Mazzoni, F. (1996) 'William E. Gladstone a Giambattista Giuliani', in Operosa parva per Gianni Antonini, ed. by D. De Robertis and F. Gavazzeni (Verona: Valdonega), pp. 311-14.

Mazzotta, G. (2004) Reading Dante (New Haven: Yale University Press).

McGovern, 'A Manchester Dante Society', Manchester Courier and Lancashire General Advertiser, February 1900, p. 3.

- 'A Manchester Dante Society', Manchester Guardian, February 1900, p. 3.

Medwin, T. (1913) The Life of Percy Bysshe Shelley (Oxford: Oxford University Press).

Mercer, A. (2019) The Collaborative Literary Relationship of Percy Bysshe Shelley and Mary Wollstonecraft Shelley (New York and London: Routledge).

Mermin, D. (1993) Godiva's Ride: Women of Letters in England, 18301880 (Bloomington: Indiana University Press).

Milbank, A. (1998) Dante and the Victorians (Manchester: Manchester University Press).

Miller, C. (2003) 'John Flaxman's Working Copy of Dante's Divina Commedia', Italian Studies, 58:1, pp. 75-87.

Miller, E. C. (2016) 'Reading in Review: The Victorian Book Review in the New Media Moment', Victorian Periodicals Review, 49: 4, pp. 626-42.

Milner, S. (2013) 'Manufacturing the Renaissance: Modern Merchant Princes and the Origins of the Manchester Dante Society', in Culture in Manchester: Institutions and Urban Change since 1850, ed. by Mike Savage and Janet Wolff (Manchester: Manchester University Press), pp. 61-94. 
Moore, E. (1887) Time References in the Divina Commedia (London: David Nutt).

- (1889) Contributions to the Textual Criticism of the Divina Commedia, Including the Complete Collation throughout the Inferno of All the Mss. at Oxford and Cambridge (Cambridge: Cambridge University Press).

- (1890) Dante and His Early Biographers (London: Rivingtons).

- (1896-1917) Studies in Dante, 4 vols (Oxford: Clarendon Press).

Morley, J. (1903) Life of William Ewart Gladstone, 3 vols (London: Macmillan).

Mortimer, J. (1908) Manchester Literary Club: Some Notes on its History, 1862-1908 (Manchester: Manchester City News Co.).

Mosk Packer, L. (1963) Christina Rossetti (Berkeley: University of California Press).

Moss, A. (1996) Printed Commonplace Books and the Structuring of Renaissance Thought (Oxford: Oxford University Press).

Moulton, R. G. (1886) The University Extension Movement (London: $\mathrm{n}$. pub).

- (1890) Address on the University Extension Movement (Philadelphia: American Society for the Extension of University Teaching).

Nasti, P. and C. Rossignoli (2013) 'Introduction', in Interpreting Dante: Essays on the Traditions of Dante Commentary, ed. by P. Nasti and C. Rossignoli (Notre Dame: University of Notre Dame Press).

O'Connell, A. (2011) 'Dante's Linguistic Detail in Shelley's Triumph of Life', CLCWeb: Comparative Literature and Culture, 13:4, http://docs. lib.purdue.edu/clcweb/vol13/iss4/13.

O’Connor, A. (2012) 'Dante Alighieri from Absence to Stony Presence: Building Memories in Nineteenth-Century Florence', Italian Studies, 67 (3), pp. 307-35.

O'Gorman, F. (2012) 'Matthew Arnold and Rereading', The Cambridge Quarterly, 41, pp. 245-61.

Oliphant, M. (1876) The Makers of Florence: Dante, Giotto, Savonarola and Their City (London: Macmillan).

Owings, F. N. (1978) The Keats Library: A Descriptive Catalogue (KeatsShelley Memorial Association: University of California).

Oxford Dante Society (1920) The Oxford Dante Society: A Record of Forty-Four Years, 1876-1920 compiled by Paget Toynbee (Oxford: Printed for Private Publication).

Ozanam, F. (1840) Dante et la philosophie catholique au treizième siècle (Paris: Olivier Fulgence).

Parker, D. (1993) Commentary and Ideology: Dante in the Renaissance (Durham and London: Duke University Press). 
Perini, N. (1908) Lectures on Dante: Delivered to the Students of Italian at King's College (London: Hachette).

Petroni, S. E. (1819) La Divina Commedia. Nuova edizione corretta da S.

E. Petroni, 3 vols (London: Schulze e Dean).

Phillimore, C. M., 'Dante's Paradise', St. Paul's Magazine, April 1871, pp. 63-72.

- (1887) Studies in Italian Literature, Classical and Modern (London: S. Low, Marston, Searle \& Rivington).

- (1898) Dante at Ravenna (London: Elliot Stock).

Pite, R. (1994) The Circle of Our Vision: Dante's Presence in English Romantic Poetry (Oxford: Clarendon Press).

Pollack-Pelzner, D. (2007) 'Revisionary Company: Keats, Homer, and Dante in the Chapman Sonnet', Keats-Shelley Journal, 56, pp. 39-49.

Powell, J. (1992) 'Small Marks and Instinctual Responses: A Study in the Uses of Gladstone's Marginalia', Nineteenth-Century Prose, 19, pp. 1-17. Price, L. (2000) The Anthology and the Rise of the Novel (Cambridge: Cambridge University Press).

Prince, K. (2008) Shakespeare in the Victorian Periodicals (New York: Routledge).

Purvis, J. (1991) A History of Women's Education in England (Milton Keynes: Open University Press).

Quarterly Review, 'Publications of The Arundel Society', October 1858, pp. 277-325.

Raben, J. (1963) 'Milton's Influence on Shelley's Translation of Dante's "Matilda Gathering Flowers", The Review of English Studies, 14:54, pp. 142-56.

Ramm, A. (1970) 'The Gladstone Diaries, Vols. i and ii by W. E. Gladstone and M. R. D. Foot', The English Historical Review, 85, pp. 591-3.

- (1992) 'Gladstone as a Man of Letters', Nineteenth Century Prose, 19, pp. 1-17.

Raven, J., H. Small, and N. Tadnor, eds (1996) The Practice and Representation of Reading in England (Cambridge: Cambridge University Press).

Raven, J. (2014) 'The Industrial Revolution of the Book', in The Cambridge Companion to the History of the Book (Cambridge: Cambridge University Press), pp. 143-61.

Ravinthiran, V. (2011) 'Dante and Shelley's Terza Rima', Essays in Criticism, 61:2, pp. 155-72.

Ricci, L. (1908) 'Preface', in Lectures on Dante: Delivered to the Students of Italian at King's College, ed. by N. Perini (London: Hachette), pp. v-xi. Roach, J. (2008) Public Examinations in England, 1850-1900 (Cambridge: Cambridge University Press). 
Roberts, R. D. (1914) Eighteen Years of University Extensions (Cambridge: Cambridge University Press).

Roe, D. (2007) Christina Rossetti's Faithful Imagination: The Devotional Poetry and Prose (Basingstoke and New York: Palgrave Macmillan).

- (2011) The Rossettis in Wonderland (London: Haus Publishing).

Rose, J. (2010) The Intellectual Life of the British Working Classes, 2nd ed. (New Haven: Yale University Press).

Rose, M. (1990) 'Settlement of University Men in Great Towns: University Settlements in Manchester and Liverpool', Transactions of the Historic Society of Lancashire and Cheshire, pp. 143-4.

- (1995) Everything Went On at the Round House: A Hundred Years of the Manchester University Settlement (Manchester: Manchester University Press).

Rosen, A. (1979) 'Emily Davies and the Women's Movement 1862-1867', Journal of British Studies, 19:1, pp. 101-21.

Rossetti, C. G., 'Dante: An English Classic', Churchman's Shilling Magazine and Family Treasury, 2, 1867, pp. 200-5.

- 'Dante, The Poet Illustrated Out of the Poem, Century Magazine, 27 February 1884, pp. 566-73.

- (1908) The Family Letters of Christina Georgina Rossetti: With some supplementary letters and appendices, ed. by William Micheal Rossetti (London: Brown, Longham \& Co.).

- (1997-2007) The Letters of Christina Rossetti 1887-1894, ed. by A. H. Harrison, 4 vols (Bloomington: University of Virginia Press).

Rossetti, D. G. (1861) The Early Italian Poets from Ciullo d'Alcamo to Dante Alighieri (1100-1200-1300) in the Original Metres Together with Dante's Vita Nuova (London: Smith, Elder and Co., 1861).

Rossetti, G. (1832) Sullo Spirito Antipapale che produsse la riforma, e sulla segreta influenza ch'esercitò nella letteratura d'Europa e specialmente d'Italia (London: Stampato per l'autore).

- (1834) Disquisitions on the Antipapal Spirit which Produced the Reformation; Its Secret Influence on the Literature of Europe in General and of Italy in Particular, trans. by Caroline Ward, 2 vols (London: Smith, Elder and Co.).

- (1842) La Beatrice di Dante: Ragionamenti Critici di Gabriele Rossetti (London: n. pub.).

Rossetti, M. F. (1871) A Shadow of Dante: Being an Essay towards Studying Himself, His World, and His Pilgrimage (London: Rivingtons).

- (1889) A Shadow of Dante: Being an Essay towards Studying Himself, His World, and His Pilgrimage (Boston: Robert Brother).

- (1901) A Shadow of Dante: Being an Essay towards Studying Himself, His World, and His Pilgrimage (London: Longman and Co.). 
- (1904) A Shadow of Dante: Being an Essay towards Studying Himself, His World, and His Pilgrimage (Boston: Little and Brown).

- (2011) Un'ombra di Dante: ovvero un saggio per studiare l'autore, il suo mondo e il suo pellegrinaggio, ed. and trans. by Paolo De Ventura (Lanciano: Rocco Carabba).

Rossetti, W. M. (1865) 'Introduction', in The Comedy of Dante Allighieri: The Hell, translated into blank verse by W. M. Rossetti, with intr. and notes (London: Macmillan), pp. vii-xx.

- (1906) Some Reminiscences of William Michael Rossetti (London: Brown Langham).

- (1977) The Diary of W. M. Rossetti, 1870-1873, ed. by Odette Bernard (Oxford: Clarendon Press).

Rowbotham, S. (1965) 'Travellers in a Strange Country: Responses of Working Class Students to the University Extension Movement - 18731910', History Workshop Journal, 12, pp. 62-95.

Ruskin, J. (1843-60) Modern Painters, 5 vols (London: Smith, Elder and Co.), II, pp. 215-21 and 225-9.

- (1851-1853) The Stones of Venice, 3 vols (London: Smith, Elder and Co.)

- (1902) Of Queen's Gardens (London: Ballantyne Press).

Saglia, D. (2018) European Literatures in Britain, 1815-1832: Romantic Translations: Romantic Translations (Cambridge: Cambridge University Press).

Saly, J. (1965) 'Keats's Answer to Dante: “The Fall of Hyperion”, KeatsShelley Journal, 14, pp. 65-78.

Saturday Review of Politics, Literature, Science and Art, 'Dante's Vita Nuova in English', October 1862, pp. 517-18.

— 'A Shadow of Dante', 25 November 1871, pp. 690-1.

— 'Dante's Divina Commedia', 13 April 1889, pp. 447-8.

— 'The Divine Comedy Again', 8 November 1902, p. 587.

Scartazzini, G. A. (1869) Dante Alighieri: seine Zeit, sein Leben, und seine Werke (Biel: Steinheil).

- (1881) Dante in Germania (Milano: Hoepli).

- (1896-99) Enciclopedia dantesca: Dizionario critico e ragionato di quanto concerne la vita e le opere di Dante Alighieri, 3 vols (Milan: U. Hoepli).

Scott, N. (1985) The Poetics of Belief: Studies in Coleridge, Arnold, Pater, Santayana, Stevens and Heidegger (Chapel Hill: University of North Carolina Press).

Scragg, B. (2000) 'Mrs Rylands and the Spencer Library', Bulletin of the John Rylands University Library of Manchester, 82:1, p. 217.

Shattock, J., ed. (2001) Women and Literature in Britain, 1800-1900 (Cambridge: Cambridge University Press). 
- (2002) 'Reviewing Generations: Professionalism and the Mid-Victorian Reviewer', Victorian Periodicals Review, 35:4, pp. 384-400.

Sheehan, D. (1941) 'The Manchester Literary and Philosophical Society', Isis, 33:4, pp. 519-23.

Shelley, M. Wollstonecraft (1987) The Journals of Mary Shelley, ed. by Paula R. Feldman and Diana Scott-Kilvert, 2 vols (Oxford: Clarendon Press).

Shelley, P. B. (1820) Prometheus Unbound: A Lyrical Drama in Four Acts: With Other Poems (London: C. and J. Ollier).

- (1821) 'A Defence of Poetry', in Peacock's 'Four Ages of Poetry', Shelley's 'Defence on Poetry,' Browning's 'Essay on Shelley', ed. by Herbert F. Brett-Smith (Oxford: Blackwell), pp. 23-59.

- (1852) 'A Defence of Poetry', in Essays, Letters from Abroad: Translations and Fragments, ed. by Mary Wollstonecraft Shelley, vol. 1 (London: Moxon), pp. 3-48.

- (1926-30) The Complete Works of Percy Bysshe Shelley, ed. by Roger Ingpen and Walter E. Peck, 10 vols (London: Ernest Benn).

- (1964) The Letters of Percy Bysshe Shelley, ed. by F. L. Jones, 2 vols (Oxford: Clarendon Press).

- (1993) The Prose Works of Percy Bysshe Shelley, ed. by E. B. Murray (Oxford: Clarendon Press).

Sherif, A. (2017) 'Book Histories, Material Culture, and East Asian Studies', Verge: Studies in Global Asias, 3:1, pp. 35-53.

Sherman, W. H. (2008) Used Books: Marking Readers in Renaissance England (Philadelphia: University of Pennsylvania Press).

Shore, A. (1886) Dante for Beginners: A Sketch of the Divina Commedia (London: Chapman and Hall).

Sleeves, H. R. (1913) Learned Societies and English Literary Scholarship in Great Britain and the United States (New York: Columbia University Press). Spectator, 'The Temple Classics', 11 February 1899, p. 209.

Speight, K. (1957) Manchester Dante Society: A Short Account of the First Fifty Years (Manchester: Morris and Yeaman Printers).

- (1961) 'The John Rylands Dante Collection', Bulletin of the John Rylands Library, 44, pp. 175-212.

Speller, J. L. (1977) Christ, Faith and Language in the Religious Thought of Matthew Arnold (Oxford: Oxford University Press).

Spender, D. (1989) 'Women and Literary History', in The Feminist Reader: Essays in Gender and The Politics of Literary Criticism, ed. by Catherine Belsey and Jane Moore (Basingstoke: Macmillan Education), pp. 21-34. Straub, J. (2000) A Victorian Muse: The Afterlife of Dante's Beatrice in Nineteenth-Century Literature (London: Continuum).

Sturrock, J. (2006) 'Establishing Identity: Editorial Correspondence from the Early Years of "The Monthly Packet"', Victorian Periodicals Review, 39, pp. 266-79. 
St Clair, W. (2004) The Reading Nation in the Romantic Period (Cambridge: Cambridge University Press).

Super, R. (1960-77) 'Preface to "Dante and Beatrice", in The Complete Prose Works of Matthew Arnold, ed. by Richard Super, 11 vols (Ann Arbor: University of Michigan Press), III, p. 7.

Swann, J. (1908) Manchester Literary Club: Some Notes on Its History, 1862-1908 (Manchester: Manchester City News).

Symonds, A. J. (1872) An Introduction to the Study of Dante (London: Smith, Elder and Co.).

Tablet, 'The Manchester Dante Society and Valgimigli', 1910, p. 24.

— 'The Dante Centenary', 27 August 1921, p. 7.

- 'The Manchester Dante Society: Twenty-First Anniversary', 7 January 1928, pp. 21-2.

Thompson, A. (1991) 'George Eliot, Dante and Moral Choice in Felix Holt, the Radical', Modern Language Review, 86:3, pp. 553-66.

- (1998) George Eliot and Italy: Literary, Cultural and Political Influences from Dante to the Risorgimento (Basingstoke and New York: Palgrave Macmillan).

- (2008) 'George Eliot's Borrowings from Dante: A List of Sources', George Eliot George Henry Lewes Studies, 44/45, pp. 26-74.

Times, 'Mr. Robert Wickham, late of No. 10', 24 May 1852, p. 2.

— 'Bombay by Steam', 18 June 1852, p. 1.

Tinkler-Villani, V. (1989) Visions of Dante in English Poetry: Translations of the Commedia from Jonathan Richardson to William Blake (Amsterdam: Rodopi).

Tipperary Free Press, 'Mr Wright's Lectures', 14 November 1849, p. 2.

Tognarelli, C. (2012) 'Il mito di Dante nelle opere del Carducci Giovane', La Rassegna della Letteratura Italiana, 116, 513-26.

Tomlinson, C. 'A Dante Society for London', Athenaeum, 1894, p. 792.

Toynbee, P. (1912) 'The Centenary of the Completion of Cary's "Dante”, The Modern Language Review, 7:3, pp. 326-9.

- (1926) 'The Oxford Dante', Annual Reports of the Dante Society, 42-4, pp. 19-44.

Toynbee, P. J. (1898) A Dictionary of Proper Names and Notable Matters in the Works of Dante (Oxford: Clarendon Press).

- (1900) Dante Alighieri: His Life and Works (London: Methuen \& Co.).

- (1902) Dante Studies and Researches (London: Methuen \& Co.).

- (1905) 'Chronological List of English Translations from Dante: From Chaucer to the Present Day', Annual Reports of the Dante Society, 24, pp. 1-107.

- (1909) Dante in English Literature from Chaucer to Cary (1380-1844), 2 vols (London: Methuen \& Co.). 
- (1921a) Britain's Tribute to Dante in Literature and Art: A Chronological Record of 540 Years (c. 1380-1920) (Oxford: Oxford University Press).

- (1921b) Dante Studies (Oxford: Clarendon Press).

- (1926) 'Oxford Dante', Annual Reports of the Dante Society, 42-44, $19-44$.

Tozer, H. F. “"A Shadow of Dante: Being an Essay towards Studying Himself, His World, and His Pilgrimage" by Maria Rossetti. 1871', Academy, 15 December 1871, pp. 551-2.

- (1901) An English Commentary to Dante's Divina Commedia (Oxford: Clarendon Press).

Trilling, L. (1952) 'A Great Instrument of Devotion', The American Scholar, 21, pp. 496-501.

Valgimigli, A. (1898) 'Il culto di Dante in Inghilterra', Giornale dantesco, 3, pp. 1-22.

- (1904) La forza morale di Dante e gli Anglo-Sassoni (Florence: L. S. Olschki).

- 'Dante Studies in England', Tablet, 24 September 1921a, pp. 393-5.

- 'Dante Studies in England', Tablet, 1 October 1921b, pp. 436-7.

- (1932) La colonia italiana a Manchester (Florence: Ariani).

Van Arsdel, R. and J. Don Vann, eds (2016) Victorian Periodicals and Victorian Society (Toronto: University of Toronto Press).

Vassallo, P. (2000) 'Keats's "Dying into Life": The Fall of Hyperion and Dante's Purgatorio', in Challenge of Keats: Bicentenary Essays, 17951995, ed. by A. C. Christensen (Amsterdam: Rodopi), pp. 206-17.

Vernon, W. W. (1906) The Contrasts in Dante: A Lecture Delivered at the University on 24th October 1906 (Manchester: The University Press).

Villani, G. (1896) Selections from the First Nine Books of the Croniche fiorentine of Giovanni Villani, ed. by Philip H. Wicksteed and trans. by Rose E. Selfe (Westminster: Constable \& Co.).

Waller, R. D. (1932) The Rossetti Family: 1824-1854 (Manchester: Manchester University Press).

Webb, T. (1976) The Violet in the Crucible: Shelley and Translation (Oxford: Clarendon Press).

Weinberg, A. M. (1991) Shelley's Italian Experience (London: Macmillan). - (2012) 'Shelley and the Italian Tradition', in The Oxford Handbook of Percy Bysshe Shelley, ed. by M. O'Neill and A. Howe (Oxford: Oxford University Press), pp. 444-59.

Weintraub, S. (1978) Four Rossettis: A Victorian Biography (London: W. H. Allen).

Westminster Review, 'Belles Lettres', April 1862, pp. 586-604.

— 'The Abbé Lamennais on Dante', 30 (1866) pp. 371-2. 
Whiting, M. (1921) 'The Dante Sexcentenary of 1865', Music \& Letters, 2:2, pp. 172-82.

Wicksteed, P. H. (1879) Dante: Six Sermons (London: C. Kegan Paul \& Co.).

- (1887) Syllabus of a Course of Lectures on Dante: Second Part (London: Taylor \& Francis).

- (1888) Syllabus of a Course of Lectures on Dante (London: Taylor \& Francis).

- (1890) Dante: Six Sermons, 2nd edn (London: Elkin Matthews).

- (1894) Syllabus of a Course of Lectures on Dante's Inferno (London: Hampton and Co.).

- (1896) 'Prefatory Note', in G. Villani, Selections from the First Nine Books of the Croniche fiorentine of Giovanni Villani, ed. by Philip H. Wicksteed and trans. by Rose E. Selfe (Westminster: Constable \& Co.), p. i.

- (1898) A Provisional Translation of the Early Lives of Dante and of His Poetical Correspondence with Giovanni del Virgilio (Hull: Elsom and Co.).

- (1901) Syllabus of a Course of Twelve Lectures on Dante's Purgatorio (Cambridge: Cambridge University Press).

- (1903) Syllabus of a Course of Twelve Lectures on Dante (Manchester: Victoria University Extension Lectures).

- (1904a) 'Edward Moore Tutte le Opere di Dante Alighieri', Hibbert Journal, 2, pp. 600-2.

- (1904b) “"Treachery of Ciphers” Review of Moore's Studies in Dante, 3rd Series', Hibbert Journal, 2, pp. 634-6.

- (1904c) Syllabus of a Course of Twelve Lectures on Dante (Manchester: Victoria University Extension Lectures).

- (1908) 'La Vita Nuova di Dante Alighieri per cura di M. Barbi', Modern Language Review, 3, p. 183.

- (1909) 'La Quaestio de Aqua et Terra di Dante Alighieri by Vincenzo Biagi', Modern Language Review, 4.2, pp. 254-8.

- (1910) 'Dante. Quaestio de Aqua et Terra by Charles Lancelot Shadwell', Modern Language Review, 5, pp. 255-6.

- (1913) Dante and Aquinas (London: J. M. Dent).

- (1916) 'On the Disputed Reading in Dante's Epist. V' 129', Modern Language Review, 11, p. 69.

- (1921a) 'Dante and the Latin Poets', in Dante: Essays in Commemoration 1321-1921, ed. by the Dante Sexcentenary Committee (London: University of London Press), pp. 157-88.

- (1921b) 'The Ethical System of the Inferno', Modern Language Review, 16, pp. 265-80. 
- (1922) From Vita Nuova to Paradiso: Two Essays on the Vital Relationship between Dante's Successive Works (Manchester: Manchester University Press).

Windscheffel, R. Clayton (2001) 'W. E. Gladstone: An Annotation Key', Notes and Queries, 48, pp. 140-3.

- (2003) 'Enlarging the Text': A Cultural History of William Ewart Gladstone's Library and Reading (Unpublished doctoral thesis, University of Liverpool).

- (2007) "Gladstone and Dante: Victorian Statesman, Medieval Poet by Anne Isba", Review of Gladstone and Dante: Victorian Statesman, Medieval Poet by Anne Isba', The English Historical Review, 122, pp. 1101-3.

- (2008) Reading Gladstone (Basingstoke: Palgrave Macmillan).

Witte, K. (1879) Dante-Forschungen: Altes und Neues 2 vols (Heilbronn: Gebr. Henninger).

- (1898) Essays on Dante by Karl Witte, ed. by Philip H. Wicksteed and trans. by C. M. Lawrence (London: Duckworth and Co.).

White, A. (1988) 'Class, Culture and Control: The Sheffield Athenaeum Movement and the Middle Class 1847-64', in The Culture of Capital: Art, Power and the Nineteenth-Century Middle Class, ed. by Janet Wolff and John Seed (Manchester: Manchester University Press), pp. 83-116. Wolff, J. and J. Seed, eds (1988) The Culture of Capital: Art, Power and the Nineteenth-Century Middle Class (Manchester: Manchester University Press).

Wolff, J. and M. Savage, eds (2013) Culture in Manchester: Institutions and Urban Change since 1850 (Manchester: Manchester University Press).

Wolfson, S. (2015) Reading John Keats (Cambridge: Cambridge University Press).

Woodhouse, J. R. (2000) 'Dante Gabriel Rossetti's Translation and Illustration of the Vita Nuova', in Britain and Italy from Romanticism to Modernism, ed. by Martin McLaughlin (Oxford: Legenda), pp. 67-86.

Woolford, J. (1982) 'Periodicals and the Practice of Literary Criticism, 1855-64', in The Victorian Periodical Press: Samplings and Soundings, ed. by Joanne Shattock and Michael Woolf (Leicester: Leicester University Press), pp. 3-28.

Yeates, F. A. (1951) 'Transformations of Dante's Ugolino', Journal of the Warburg and Courtauld Institutes, 14:1, pp. 92-117.

Zancani, D. (1998) 'Una biblioteca di cent'anni fa: la "Dante Collection" di Paget Toynbee (1855-1932)’, La Bibliofilía, 100, pp. 495-12.

Zimmerman, S. (2019) The Romantic Literary Lecture in Britain (Oxford: Oxford University Press). 


\section{Online resources}

Grant, A. H., 'Barlow, Henry Clark (1806-1876)', in Oxford Dictionary of National Biography, rev. by Alison Milbank, www.oxforddnb.com [accessed 6 May 2015].

Manchester Literary and Philosophical Society, Our History, www. manlitphil.ac.uk/our-history [accessed 30 October 2014].

'Manchester Literary Club', in The National Archives, www.http:// discovery.nationalarchives.gov.uk [accessed 7 March 2020].

Morris, L. A. 'Keats Family Books in the Harvard Keats Collection' http:// hcl.harvard.edu/libraries /houghton /collections /modern/keats.cfm [accessed 12 May 2019].

'Mudie's Circulating Library' (2011) UCL The Bloomsbury Project, www. ucl.ac.uk/bloomsbury-project/institutions/mudie.html [accessed 15 April 2017].

'Philip Henry Wicksteed', in Encyclopaedia Britannica, www.britannica. com [accessed 23 May 2016].

Roda, M., 'Baldassarre Lombardi', in Dizionario Biografico degli Italiani, www.treccani.it/ [accessed 10 September 2017].

Steedman, Ian (2004) 'Wicksteed, Philip Henry (1844-1927)', in Oxford Dictionary of National Biography, www.oxforddnb.com [accessed 23 May 2016].

The University of Virginia Press (2006) The Letters of Christina Georgina Rossetti: A Digital Edition, https://rotunda.upress.virginia.edu/ [accessed 20 June 2019].

Vatteroni, S. M., 'La collezione di Prose e poesie liriche di Dante Allighieri', in La Biblioteca del Fondo Alessandro Torri, un protagonista della vita culturale dell'Ottocento pisano, http://biblio.sns.it/en/collezioni/ letteratura/torri/mostra/dantealighieri/ [accessed 23 June 2017].

Ward, L. (2016) 'A Translation of a Translation: Dissemination of the Arundel Society's Chromolithographs' (unpublished doctoral dissertation, The Australian National University) in Semantic Scholar, www.semanticscholar.org/paper/A-translation-of-a-translation \%3A-D issemination-of-Ward/eedd95ae0f904ef32644b98bca1eb9ff5dd47148 [accessed 20 June 2019].

Zweig, R. M. (1984) 'The Victorian Dante: Dante and Victorian Literary Criticism' (unpublished doctoral dissertation, College University of New York) in ProQuestDissertations and Theses Global, https://search. proquest.com/docview/303289310? accountid=12253 [accessed 14 April 2015]. 